\title{
The End of the World
}

\author{
and Other Teachable Moments
}




\section{Series Board}

James Bernauer

Drucilla Cornell

Thomas R. Flynn

Kevin Hart

Richard Kearney

Jean-Luc Marion

Adriaan Peperzak

Thomas Sheehan

Hent de Vries

Merold Westphal

Michael Zimmerman 


\section{John D. Caputo, series editor}



Continental

Philos OPHY 
This page intentionally left blank 


\section{MICHAEL NAAS}

\section{The End of the World and Other Teachable Moments}

Jacques Derrida's Final Seminar 
Copyright (C) 2015 Fordham University Press

All rights reserved. No part of this publication may be reproduced, stored in a retrieval system, or transmitted in any form or by any means-electronic, mechanical, photocopy, recording, or any other-except for brief quotations in printed reviews, without the prior permission of the publisher.

Fordham University Press has no responsibility for the persistence or accuracy of URLs for external or third-party Internet websites referred to in this publication and does not guarantee that any content on such websites is, or will remain, accurate or appropriate.

Fordham University Press also publishes its books in a variety of electronic formats. Some content that appears in print may not be available in electronic books.

Library of Congress Cataloging-in-Publication Data is available from the publisher.

Printed in the United States of America

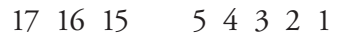

First edition 
In memory of Helen Tartar 
This page intentionally left blank 